2. To: (Receiving Organization)

Distribution

5. Proj./Prog./Dept./Div.:

BCSR/MMS

8. Originator Remarks:

11. Receiver Remarks:
3. From: (Originating Organization) 67000 Boeing Computer 6. Cog. Engx::

Barxy Byron

\section{VIDON Operations Test Report for Distribution and osTI/ESTSC}

1. Eat 615742

4. Related EDT No:

None

7. Purchase Order No.

$\mathrm{N} / \mathrm{A}$

9. Equip./Component No.:

$\mathrm{N} / \mathrm{A}$

10. System/Bldg.Facility:

$\mathrm{N} / \mathrm{A}$

12. Major Assm. Dwg. No.:

N/A

13. Permit/Permit Application No.:

$\mathrm{N} / \mathrm{A}$

14. Required Responso Date:

$\mathrm{N} / \mathrm{A}$

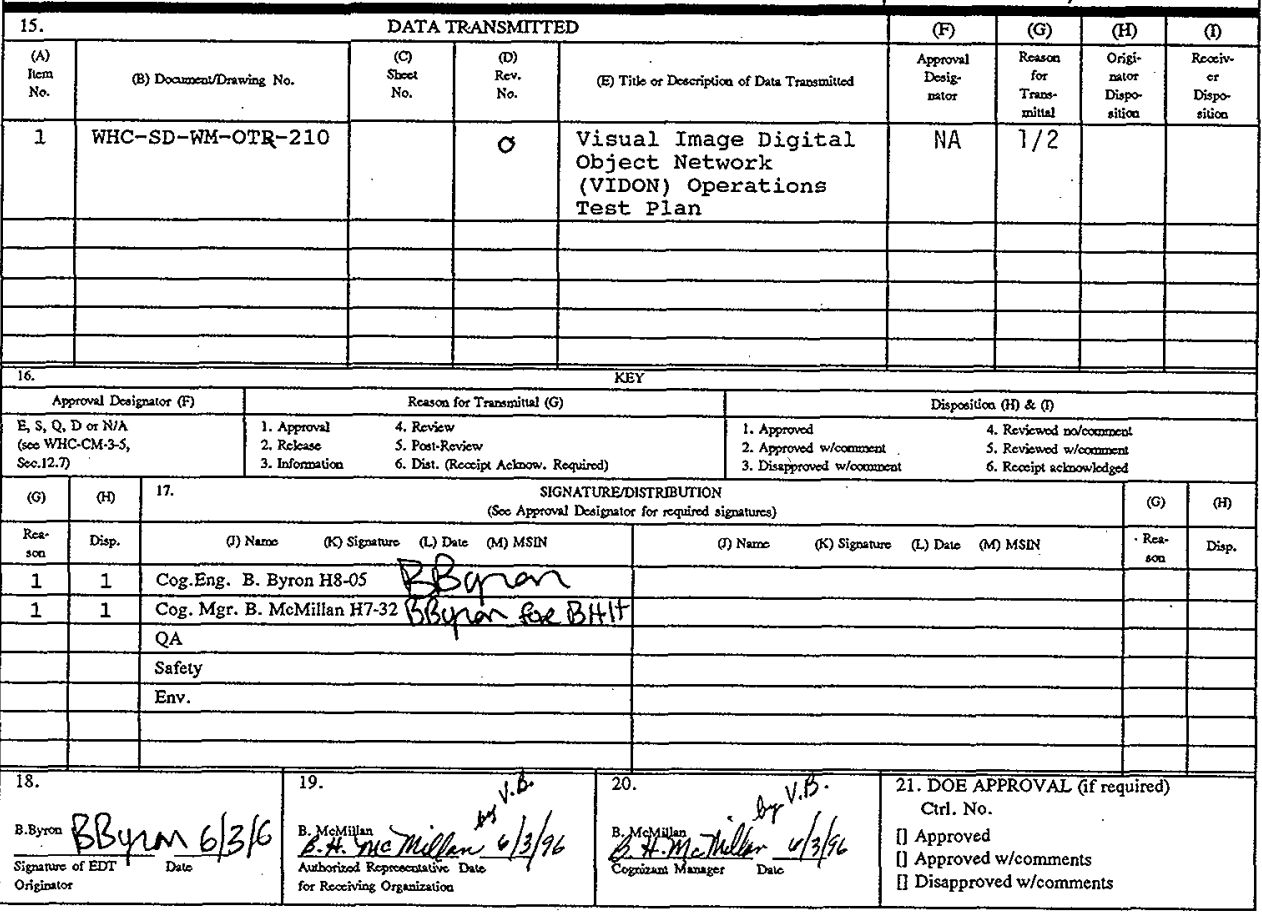




\title{
Visual Image Digital Object Network (VIDON) Operations Test Report
}

\author{
B.D. Byron \\ Westinghouse Hanford Company/Boeing Computer Services Richland \\ Richland, WA 99352 \\ U.S. Department of Energy Contract DE-ACO6-87RI10930 \\ EDT/ECN: \\ Org Code: 67100 \\ B\&R Code: YN0100000 \\ UC: UC-2030 \\ Chrige Code: MPSO0 \\ Toisil Pages: 23
}

Key Words: VIDON, Photography, Image Capture

Abstract:

This document records operation testing to ensure the VDON product is functional.

Trademarks:

cc:Mail is a trademark of Lotus Development Corporation.

TARGA is a trademark of TrueVision, Inc.

Mierosoft User Level Security (ULS) is a tredemerk of Microsoft Corporation.

Window's is a trademerk of Microsoft Corporation

Merlin is a trademark of T/One, Inc. of Quincey, MA.

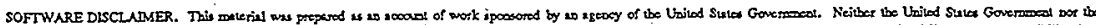

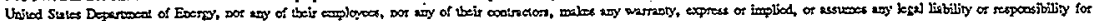

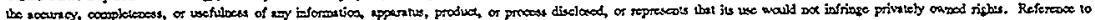

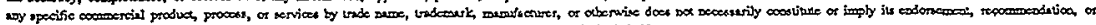

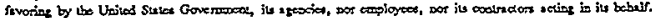

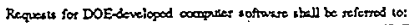

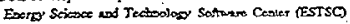

P.O. Ben 1020

Ont RLSe, TN 37831

Telepboco: 423/576-2606

F.x: $423 / 576-6436$

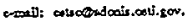

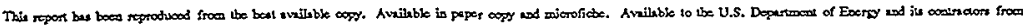

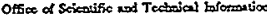

P.O. Bos 62

Ont PSBje, TN 37891

Telepboco: $423 / 576-8401$

Avilable to the pustic troon

U.S. Departicat of Comoneroo

Nationel Tesbojed Lrometion Sentios

Szass pon Rojyl Rous

Sprinefiet, VA 22161

Telipbor: 203/487-4650

Pribud in the Unitiod Sulce of Americ
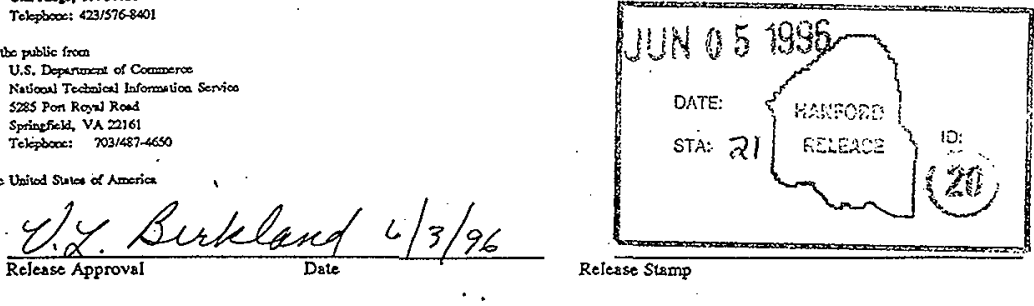

Release Stamp

Approved for Public Release 
WHC-SD-WM-OTR-210 Page 1

Rev. 0

\section{SIGN OFF:}

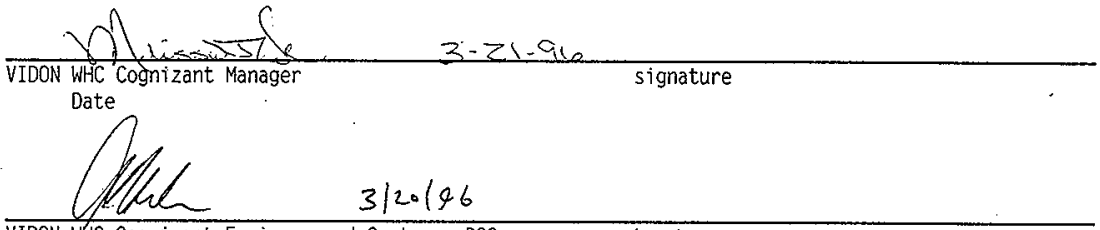

\section{VIDON WHC Cognizant Engineer and Customer POC signature}

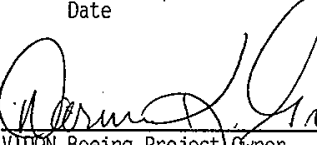

VI00 Boeing Project) Owner

Date
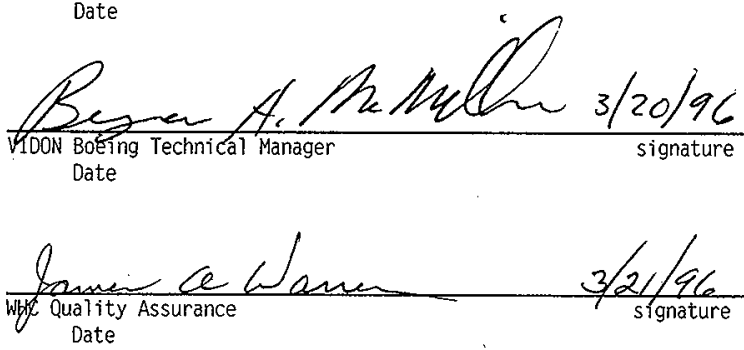


\section{FEATURES TO BE TESTED:}

Image capture and metadata input screens.

This test addresses the VIDON capture station used by the photography lab to input photos and metadata to the VIDON database.

\section{TEST DESIGN DESCRIPTIONS:}

TD 01.01-00 Security features.

TD 01.01-01. Image capture and adjustment on screen.

TD 01.01-02 Metadata input screen.

TD 01.01-03 Waste tank metadata screen appearance.

TD 01.01-04 Acceptance of the entered metadata.

\section{ORDER OF OPERATIONS:}

It is assumed that the order of operations will be as follows: Capture and adjust image until satisfied with image quality and then press the 'enter metadata screen' button. Upon entering this screen, the order of operations are irrelevant with the exception that after leaving either the Source \# text box or the Dash \# text box, the program will check the database for the existence of a record matching what is in the Source and Dash \# text boxes and will either set all appropriate fields if a record does exist or it will reset all fields to their default states if a matching record does not exist. This should be kept in mind so that metadata is not entered prior to having the database refresh the metadata fields.

\section{VALIDATION:}

Validation of the above test will be done via the VIDON retrieval station. Images and metadata input via the capture station will be available immediately after a capture has been completed.

TD 01.01-00 Security features.

The VIDON system is built around Microsoft's User Level Security (ULS) security model. The capture station software will not start if the logged on user is not a member of a group that has been authorized to use this piece of software.

TD 01.01-01 Image capture and adjustment on screen.

After pressing the capture button, the user will have the ability to adjust the contrast and brightness of the image as well as change the size and portion of the image displayed on the screen that will be saved to the database.

TD 01.01-02 Metadata input screen.

The metadata screen is used to enter into the database, information that describes the image being captured. Other than the precaution noted in the order of operations section of this document, the user is free to move about the screen in any order desired.

TD 01.01-03 Waste tank metadata screen appearance.

The waste tank metadata screen is a secondary screen that holds metadata which only applies when the image 
being captured is a waste tank. All waste tanks are designated by the first three letters of their name being 241 . When a building number that starts with 241 is entered into the Building \# text box and the focus is changed, a secondary box will appear with input boxes specific to a waste tank. The database will be queried and if a matching record exists for the entered Source and Dash \#, these fields will be populated in the same manner that the original metadata fields were populated.

TD 01.01-04 Acceptance of the entered metadata

After entering the desired metadata for the captured image, the user can either press the Save button and write this information to the database or press the Cancel button to discard this information. If an image currently exists in the database for this record, the user will have the choice to overwrite that image or cancel. 


\section{FEATURES TO BE TESTED:}

Add to inventory, remove from inventory, update of inventory status, check out of inventory, check in of inventory.

This test addresses the VIDON checkout station used by DRM in the VIDON library to keep track of photographs.

\section{TEST DESIGN DESCRIPTIONS:}

TD 01.02-00 Security features.

TD 01.02-01 Add a piece of inventory to the system.

TD 01.02-02 Update the status of the piece of inventory.

TD 01.02-03 Checkout a folder of inventory.

TD 01.02-04 Check to see if that folder is delinquent.

TD 01.02-05 Send e-mail. messages to delinquent users.

TD 01.02-06 Check in the folder of inventory.

TD 01.02-07 Optional reports.

\section{ORDER OF OPERATIONS:}

It is assumed that the order of operations will be as follows: Add one or more pieces of inventory to the VIDON system, update the status of the inventory if necessary, check out the inventory to a user, check on the delinquency of checked out inventory, check in the inventory when it is brought back.

\section{TD 01.01-00 Security features.}

The VIDON system is built around Microsoft's User Level Security (ULS) security model. The checkout station software will not start if the logged on user is not a member of a group that has been authorized to use this piece of software.

\section{TD 01.02-01. Add a piece of inventory to the system.}

From the inventory screen, it is possible to add a piece of inventory to the system. Enter in the Source \# and Dash \# of the inventory and optionally the range of Dash \#'s if more than one piece of inventory is being added. Set the status of the inventory as desired and press the 'Save' button. Verification of the newly entered inventory can be obtained by pressing the 'Mass update' button.

TD 01.02-02 Update the status of the piece of inventory.

With a Source \# in the Source \# text box, pressing the 'Mass Update' button will go to a screen in which the status of all the pieces of inventory for that Source \# can be viewed and updated.

TD 01.02-03 Checkout a folder of inventory.

From the checkout screen, it is possible to select multiple folders of inventory to be checked out to a user.

TD 01.02-04. Check to see if that folder is delinquent.

The Delinquency report can be run to show if any of the users that have checked out inventory are delinquent. 
Acceptance test plan for VIDON checkout station. ID 01.02

WHC-SD-WM-OTR-210 Page 5

Rev. 0

TD 01.02-05 Send e-mail messages to delinquent users.

If it is desired, e-mail messages stating the folder that is checked out can be sent to the patron.

TD 01.02-06 Check in the folder of inventory.

When a folder is returned to the checkout station, it is checked back in from the Check-in screen.

TD 01.02-07 Optional reports.

Two other hard copy reports, which are very paper intensive, can also be run. 
FEATURES TO BE TESTED:

Retrieval of images based on predefined as well as user generated queries. Storage and retrieval of images in local albums.

This test addresses the VIDON retrieval station used by the general population to retrieve images based on user generated queries.

\section{TEST DESIGN DESCRIPTIONS:}

TD . 01.03-00 Security features.

TD 01.03-01 User generated query of VIDON.

TD 01.03-02 Predefined tank query of VIDON.

TD 01.03-03 Tank Farms group extended privileges.

TD 01.03-04 User generated query of local album.

TD 01.03-05 Album manipulation.

TD 01.03-06 Metadata viewing.

TD 01.03-07 Image exporting.

TD 01.03-08 Optional settings.

TD 01.03-09 On line help.

\section{ORDER OF OPERATIONS:}

There is no assumed order of operations for this piece of software.

TD 01.03-00 Security features.

The VIDON system is built around Microsoft's User Level Security (ULS) security model. The retrieval station software will show different options based on the access group that the logged on user is a member of.

TD 01.03-01 User generated query of VIDON.

VIDON is set up so that the user can create an adhoc query on the fly. When in the query builder, the user has the choice of entering data and the desired search operator for non-lookup type fields. If the field being used in the query is a lookup table; the user will only be allowed to choose from the possible choices for that data field and will only have the option of no selection or equals for the search operator.

TD 01.03-02 Predefined tank query of VIDON.

There is a predefined tank query that is available for the 'Tank Query' button in which the user is only allowed to choose from tanks that have images associated with them.

TD 01.03-03 Tank Farms group extended privileges.

Members of the Tank Farms group have extended privileges in that they can see extra fields in the query builder, have waste tank metadata show up at the bottom of their medium resolution images, and have the ability to update the waste tank comment field.

TD 01.03-04 User generated query of local album.

In much the same way as the user can query the VIDON database, the user may also query any local albums that 
have been created in the past and stored on the users machine.

TD 01.03-05 Album manipulation.

Albums are the unit of storage for images. Albums may be created, opened, closed, have images added to, have images removed from, have images moved around in, be saved, renamed, and deleted. The images may be moved from either one album to another or from the results set retumed by a query. All of the menu items and buttons work on the album that currently has the focus. When opening an album, you will only see the albums not already open.

TD 01.03-06 Metadata viewing.

With the exception of the members of the Tank Farms group, all metadata stored on the server is read only and therefore cannot be changed. When images are stored in local albums, however, the user now has the option of adding a caption that will be stored with the image. The metadata for images that are brought in locally, opposed to via VIDON, can be accessed via the 'Object info' button. The metadata for VIDON supplied images can be retrieved by doing a double right click on the image.

TD 01.03-07 Image exporting.

When a medium resolution image is being viewed, it can be copied to a local file for use in other programs. The user has the option of many different formats in which to save the image.

TD 01.03-08 Optional settings.

The look and feel of the retrieval station may be tailored to the liking of the user via user selectable options. The options available to the user are: show captions, ID'S, file names, thumb nail file names below the low resolution images, change the thumbnail display size, and determine whether to show no button bar, buttons without text, button plus text below, button plus prompt.

TD 01.03-09 On line help.

Help in using this application may be obtained via the on line help file. 


\begin{tabular}{|c|c|c|c|}
\hline \multirow{2}{*}{ 洋: } & \multicolumn{2}{|c|}{ 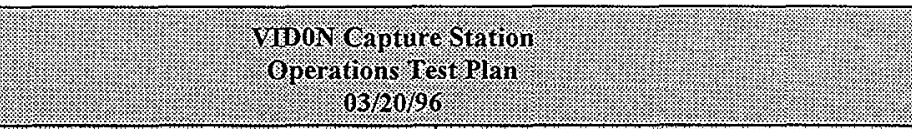 } & \multirow{2}{*}{ 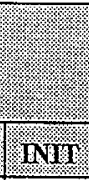 } \\
\hline & PERFORM & TXPECTEO RISSUIII & \\
\hline \multirow[t]{2}{*}{$\begin{array}{l}\text { TD } 01.01-00 \\
\text { Security Features }\end{array}$} & $\begin{array}{l}\text { Attempt to start the capture station } \\
\text { software, without being a member of } \\
\text { Photo group }\end{array}$ & $\begin{array}{l}\text { Access will be denied and an error } \\
\text { message is displayed to the user }\end{array}$ & \\
\hline & $\begin{array}{l}\text { Once the VIDON Administrator } \\
\text { adds your Hanford } \mathrm{D} \text { to the Photo } \\
\text { group, start the capture station } \\
\text { software. }\end{array}$ & $\begin{array}{l}\text { The program will come up to the main } \\
\text { screen }\end{array}$ & \\
\hline \multirow{4}{*}{$\begin{array}{l}\text { TD 01.01-01 } \\
\text { Image capture } \\
\text { and on screen } \\
\text { adjustment (File } \\
\text { Mode) }\end{array}$} & $\begin{array}{l}\text { Place the system in the file mode by } \\
\text { pushing the File button }\end{array}$ & The system will accept input from a file & \\
\hline & $\begin{array}{l}\text { Capture a file image by pressing the } \\
\text { Capture button on the menu bar and } \\
\text { perform on screen adjustments to the } \\
\text { image }\end{array}$ & $\begin{array}{l}\text { A Windows standard file open form will } \\
\text { display and allow selection of an image }\end{array}$ & \\
\hline & Select image file, and click on $\mathrm{OK}$ & $\begin{array}{l}\text { Image appears on Image processing } \\
\text { form. }\end{array}$ & \\
\hline & Or & & \\
\hline \multirow{3}{*}{$\begin{array}{l}\text { Image capture } \\
\text { and on screen } \\
\text { adjustment } \\
\text { (TARGA mode) }\end{array}$} & $\begin{array}{l}\text { Place the system in the TARGA } \\
\text { mode by pushing one of the user } \\
\text { defined TARGA based buttons }\end{array}$ & $\begin{array}{l}\text { The system will accept input from } \\
\text { TARGA board }\end{array}$ & \\
\hline & $\begin{array}{l}\text { Capture a file image by pressing the } \\
\text { Capture button on the menu bar and } \\
\text { perform on screen adjustments to the } \\
\text { image }\end{array}$ & $\begin{array}{l}\text { Image appears on Image processing } \\
\text { form. }\end{array}$ & \\
\hline & Now & & $B B$ \\
\hline \multirow[t]{2}{*}{ Image adjustment } & $\begin{array}{l}\text { Position the crop box so the section } \\
\text { of image to be captured is framed }\end{array}$ & The image is framed in the crop box & $B B$ \\
\hline & $\begin{array}{l}\text { Under the Image Menu, select } \\
\text { "Brightness/Contrast" option. }\end{array}$ & $\begin{array}{l}\text { Adjust Contrast/Brightness form appears } \\
\text { with two scroll bars set at } 50 \text {, and OK } \\
\text { and Cancel buttons. }\end{array}$ & $B B$ \\
\hline
\end{tabular}




\begin{tabular}{|c|c|c|c|}
\hline \multirow{3}{*}{ 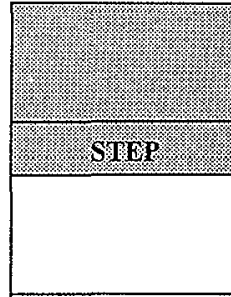 } & 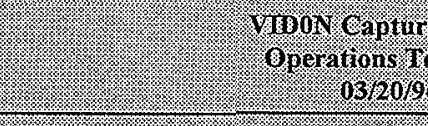 & $\begin{array}{l}\text { Station } \\
\text { Stplan }\end{array}$ & \\
\hline & PERroRMI & EXPECTEO RISUIT) & $\mathrm{NW}$ \\
\hline & $\begin{array}{l}\text { Adjust Scroll bars up or down } \\
\text { affecting the Brightness and Contrast }\end{array}$ & $\begin{array}{l}\text { Upon each reset of the scroll bar, the } \\
\text { image will repaint with the appropriate } \\
\text { change. }\end{array}$ & Bh \\
\hline \multirow[t]{4}{*}{$\begin{array}{l}\text { TD 01.01-02 } \\
\text { Metadata input } \\
\text { screen }\end{array}$} & Push 'Enter Photo Data' button. & $\begin{array}{l}\text { 'Source Meta Data' screen will apear, } \\
\text { cursor will appear in 'source \#' field. } \\
\text { Pick lists should appear for Media Type, } \\
\text { Subject Type, Site Function, Style and } \\
\text { Technique. All fields should be at their } \\
\text { default values. }\end{array}$ & $8 B$ \\
\hline & $\begin{array}{l}\text { Enter Source number of photo and } \\
\text { press tab/enter }\end{array}$ & Cursor appears in 'dash \#' field & $B$ \\
\hline & $\begin{array}{l}\text { Enter Dash number of photo and } \\
\text { press tab/enter }\end{array}$ & $\begin{array}{l}\text { If record exists for the Source/Dash } \\
\text { number, fields will change to display } \\
\text { current meta data for that record. If new } \\
\text { record, all fields will remain in their } \\
\text { default values and the cursor will simply } \\
\text { move to the Date field. }\end{array}$ & $B B$ \\
\hline & $\begin{array}{l}\text { Enter proper data for date and media } \\
\text { type. }\end{array}$ & & $B B$ \\
\hline $\begin{array}{l}\text { TD } 01.01-03 \\
\text { Appearance of } \\
\text { waste tank } \\
\text { metadata screen }\end{array}$ & $\begin{array}{l}\text { Enter Tank building number, which } \\
\text { starts with the tank designator ' } 24 l^{\prime} \text { '. } \\
\text { Press tab/enter. }\end{array}$ & $\begin{array}{l}\text { The Waste Tank Metadata form will } \\
\text { appear. }\end{array}$ & $B$ \\
\hline \multirow[t]{2}{*}{$\begin{array}{l}\text { TD } 01.01-02 \\
\text { continued }\end{array}$} & Finish entering proper metadata & & $B 8$ \\
\hline & Push save & Metadata screen will clear & $8 B$ \\
\hline $\begin{array}{l}\text { TD 01.01-04 } \\
\text { Acceptance of } \\
\text { entered metadata }\end{array}$ & $\begin{array}{l}\text { Go to retrieval station to verify new } \\
\text { or saved record. Use Query builder } \\
\text { with search criteria set to Source } \\
\text { and dash number. }\end{array}$ & $\begin{array}{l}\text { Results form will show that the saved } \\
\text { record does exist with an image. }\end{array}$ & $B B$ \\
\hline
\end{tabular}




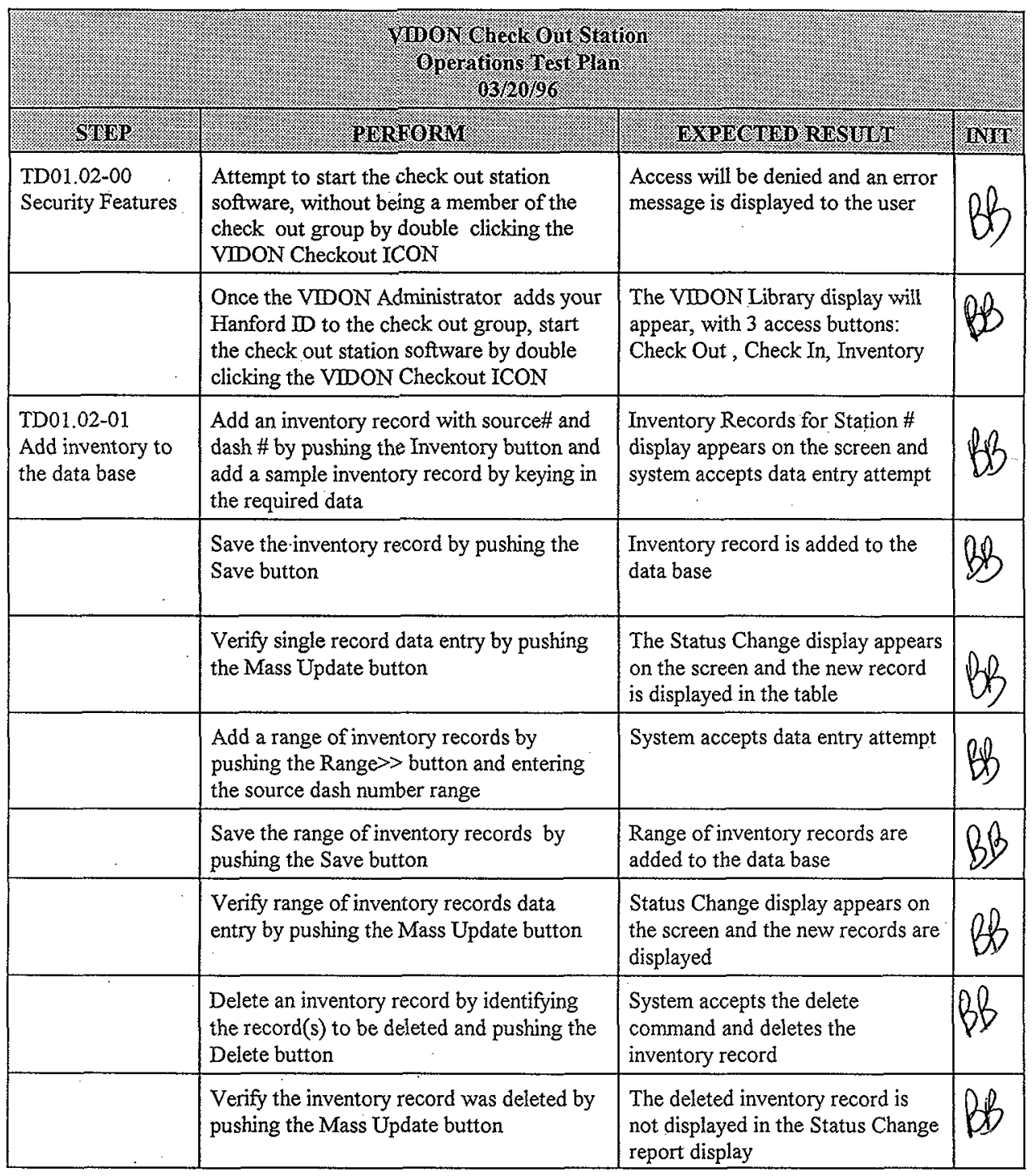




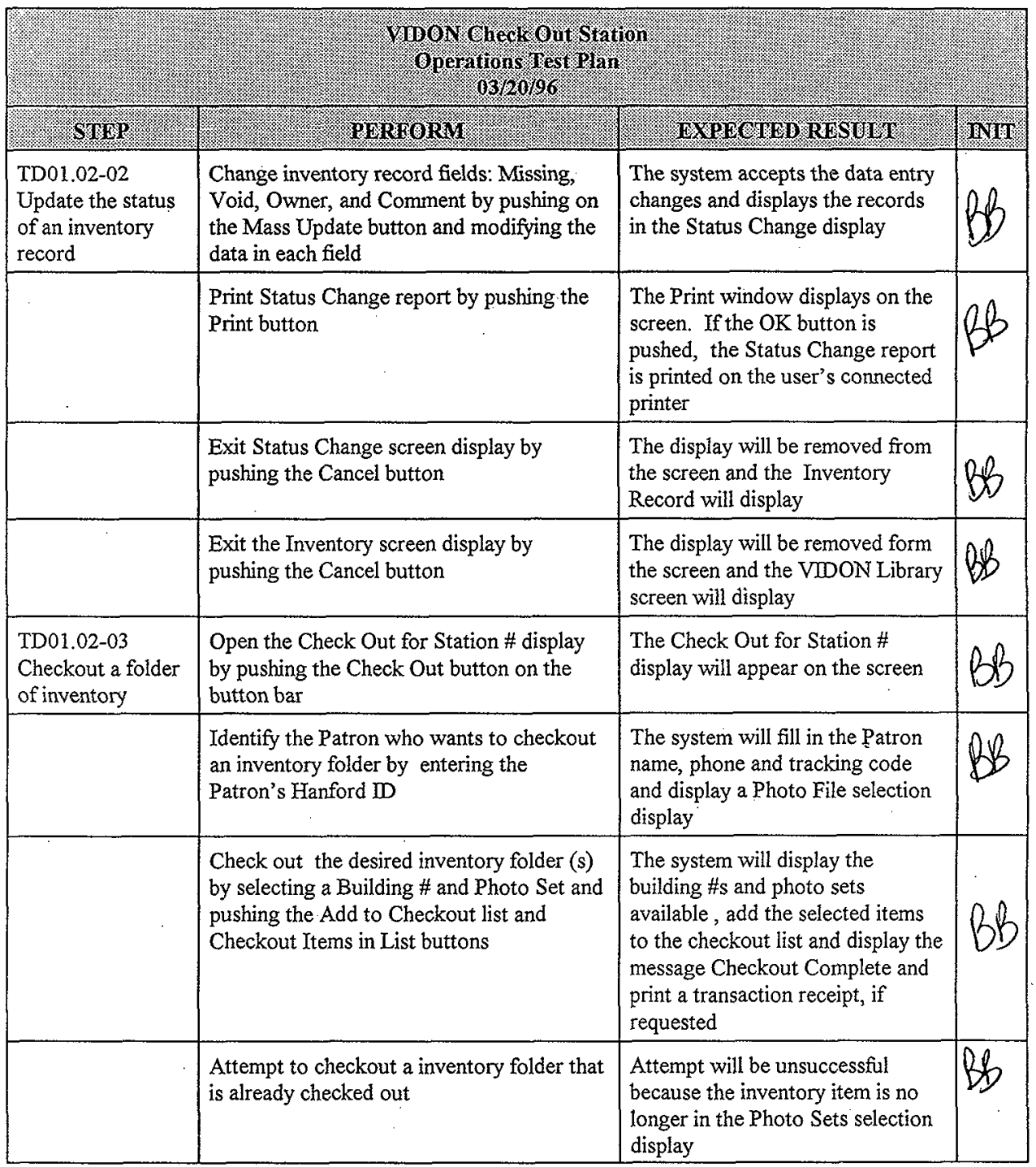




\begin{tabular}{|c|c|c|c|}
\hline \multirow{2}{*}{ 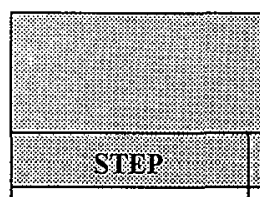 } & 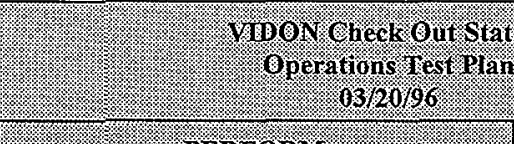 & \multicolumn{2}{|c|}{ hin: } \\
\hline & IGRFORM : & 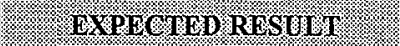 & ivig: \\
\hline & $\begin{array}{l}\text { Attempt to change the delinquency window } \\
\text { from the default } 5 \text { days to another value by } \\
\text { pushing the left and right arrow to the } \\
\text { desired \# of days }\end{array}$ & $\begin{array}{l}\text { The system will accept any value } \\
\text { from } 0 \text { days to } 10 \text { days }\end{array}$ & \\
\hline \multirow[t]{3}{*}{$\begin{array}{l}\text { TD01.02-04 } \\
\text { Check if folder is } \\
\text { delinquent }\end{array}$} & $\begin{array}{l}\text { Open the Reports display by clicking on the } \\
\text { Reports menu item }\end{array}$ & $\begin{array}{l}\text { The system will display three } \\
\text { options: Delinquency, Index and } \\
\text { Inventory by Owner }\end{array}$ & $B B$ \\
\hline & $\begin{array}{l}\text { Select the Delinquency Report by clicking } \\
\text { on the Delinquency option }\end{array}$ & $\begin{array}{l}\text { The system will display a } \\
\text { delinquency report listing all } \\
\text { folders that have not been returned } \\
\text { within the designated check out } \\
\text { period }\end{array}$ & $B b$ \\
\hline & $\begin{array}{l}\text { Print current delinquency report by } \\
\text { pushing the Print button }\end{array}$ & $\begin{array}{l}\text { The Print window displays on the } \\
\text { screen. If the OK button is } \\
\text { pushed, the delinquency report is } \\
\text { printed on the user's connected } \\
\text { printer }\end{array}$ & \\
\hline \multirow[t]{2}{*}{$\begin{array}{l}\text { TD01.02-05 } \\
\text { Send cc:Mail } \\
\text { message to } \\
\text { delinquent users }\end{array}$} & $\begin{array}{l}\text { Send a cc:Mail message to the patrons who } \\
\text { have not returned the folders within the } \\
\text { designated check out period by pushing the } \\
\text { Send cc:Mail button }\end{array}$ & $\begin{array}{l}\text { The system will prepare a cc:Mail } \\
\text { message and dispatch it to the } \\
\text { patrons-listed in the delinquency } \\
\text { report }\end{array}$ & $8 B$ \\
\hline & $\begin{array}{l}\text { Exit the delinquency report by pushing the } \\
\text { Cancel button }\end{array}$ & $\begin{array}{l}\text { The display will be removed from } \\
\text { the screen and the VDONON } \\
\text { Library screen will display }\end{array}$ & B \\
\hline \multirow[t]{2}{*}{$\begin{array}{l}\text { TD01.02-06 } \\
\text { Check in a folder } \\
\text { of inventory }\end{array}$} & $\begin{array}{l}\text { Open the Check In for Station \# display by } \\
\text { pushing the Check In button on the button } \\
\text { bar }\end{array}$ & $\begin{array}{l}\text { The Check In for Station \# display } \\
\text { will appear on the screen }\end{array}$ & $B B$ \\
\hline & $\begin{array}{l}\text { Identify the patron who wants to check in } \\
\text { an inventory folder by scrolling for their } \\
\text { Hanford Id \# by pushing the down arrow } \\
\text { and click on the highlighted Hanford Id \# }\end{array}$ & $\begin{array}{l}\text { The name of the patron appears in } \\
\text { the Name field and all checked out } \\
\text { inventory folders are displayed in } \\
\text { the Photo Set display }\end{array}$ & $B 8$ \\
\hline
\end{tabular}




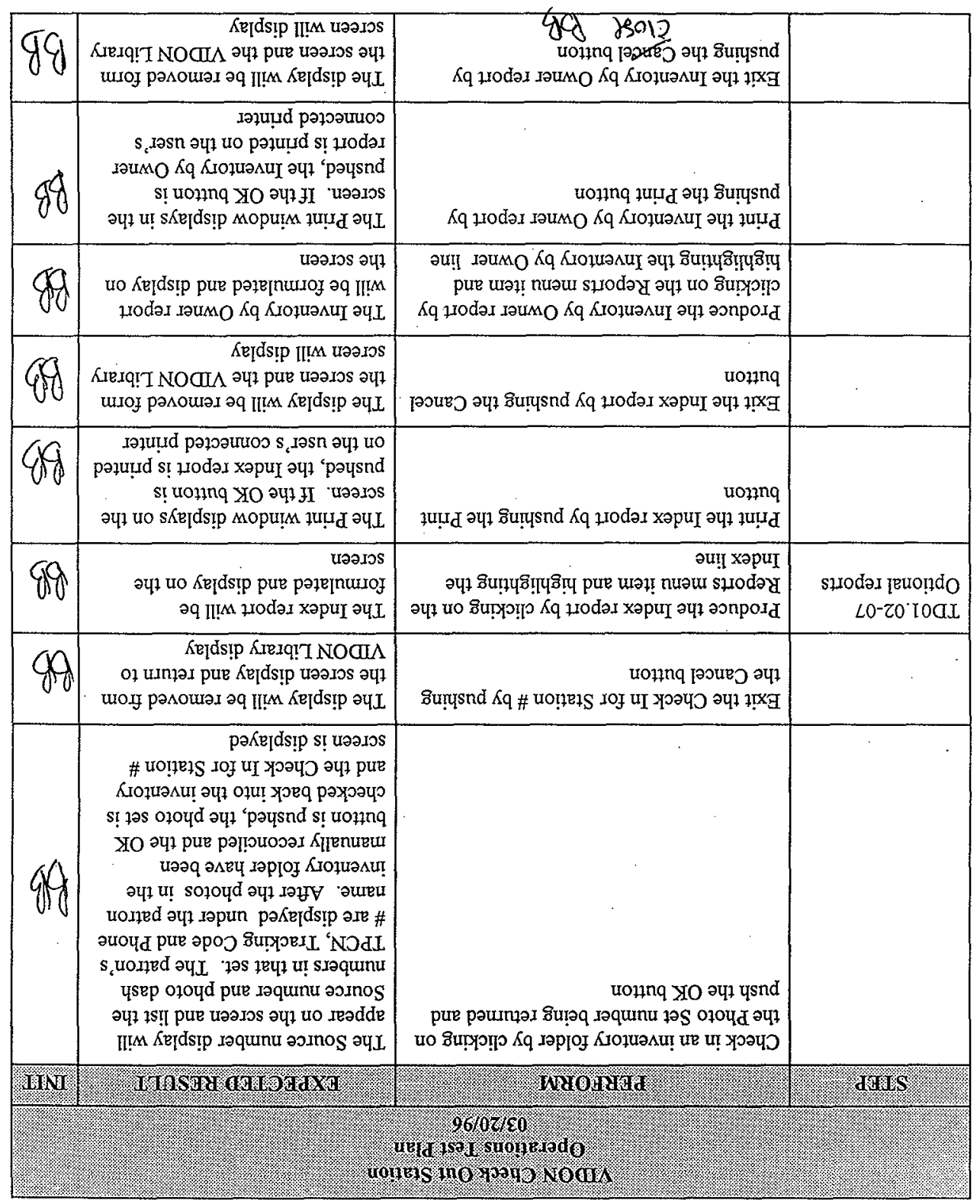




\begin{tabular}{|c|c|c|c|}
\hline (3) & 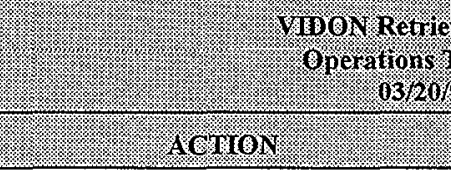 & \begin{tabular}{l|l} 
listation \\
stPlan
\end{tabular} & \\
\hline \multirow[t]{3}{*}{$\begin{array}{l}\text { TD } 01.03-00 \\
\text { Security } \\
\text { features }\end{array}$} & $\begin{array}{l}\text { Attempt to start VIDON software as a } \\
\text { General User (without being a member } \\
\text { of the Tank group) by double clicking } \\
\text { on the VIDON icon }\end{array}$ & $\begin{array}{l}\text { A screen will appear which reads "You } \\
\text { have logged onto the VIDON data base } \\
\text { group: General User" }\end{array}$ & \\
\hline & $\begin{array}{l}\text { Once the VIDON administrator adds } \\
\text { your Hanford } \mathrm{D} \text { to the Tanks group, } \\
\text { start VIDON by double clicking on the } \\
\text { VIDON icon }\end{array}$ & $\begin{array}{l}\text { A screen will appear which reads "You } \\
\text { have logged onto the VDDON data base in } \\
\text { group: Tankfarms" }\end{array}$ & B \\
\hline & Click on OK & Screen will clear & $B b$ \\
\hline \multirow[t]{5}{*}{$\begin{array}{l}\text { TD 01.03-01 } \\
\text { User } \\
\text { generated } \\
\text { query of } \\
\text { VMDON }\end{array}$} & $\begin{array}{l}\text { Bring up the VIDON database query } \\
\text { builder by either pressing the Query } \\
\text { VIDON button or by clicking on the } \\
\text { VIDON Database selection under the } \\
\text { Query menu item. }\end{array}$ & $\begin{array}{l}\text { The query builder for VDON will come } \\
\text { up and the menu items will change to } \\
\text { reflect the actions available while in the } \\
\text { query builder }\end{array}$ & BB \\
\hline & $\begin{array}{l}\text { Highlight the column labeled } \\
\text { 'Keywords'. Edit the search criteria } \\
\text { for this column by either double } \\
\text { clicking anywhere in that column or by } \\
\text { choosing Change from the Columns } \\
\text { menu item. }\end{array}$ & $\begin{array}{l}\text { The window will enlarge showing the field } \\
\text { names that are retievable, the operators } \\
\text { available for the selected field, and } \\
\text { optionally a text box in which to specify } \\
\text { criteria. }\end{array}$ & \\
\hline & $\begin{array}{l}\text { Choose "contains" from the operators } \\
\text { list box by highlighting it and type the } \\
\text { word 'tank' into the criteria text box. }\end{array}$ & $\begin{array}{l}\text { "Contains" will be highlighted and the } \\
\text { word 'tank' will be in the criteria text box. }\end{array}$ & Bby \\
\hline & Press the OK button. & $\begin{array}{l}\text { The window will shrink back to its } \\
\text { original size and the operator and criteria } \\
\text { you specified will appear under the } \\
\text { column being worked on. }\end{array}$ & $B b$ \\
\hline & $\begin{array}{l}\text { Highlight the column labeled 'Project } \\
\text { No'. Edit the search criteria for this } \\
\text { column by either double clicking } \\
\text { anywhere in that column or by } \\
\text { choosing Change from the Columns } \\
\text { menu item. }\end{array}$ & $\begin{array}{l}\text { The window will enlarge showing the field } \\
\text { names that are retievable, the operators } \\
\text { available for the selected field, and } \\
\text { optionally a text box in which to specify } \\
\text { criteria. }\end{array}$ & $B b$ \\
\hline
\end{tabular}




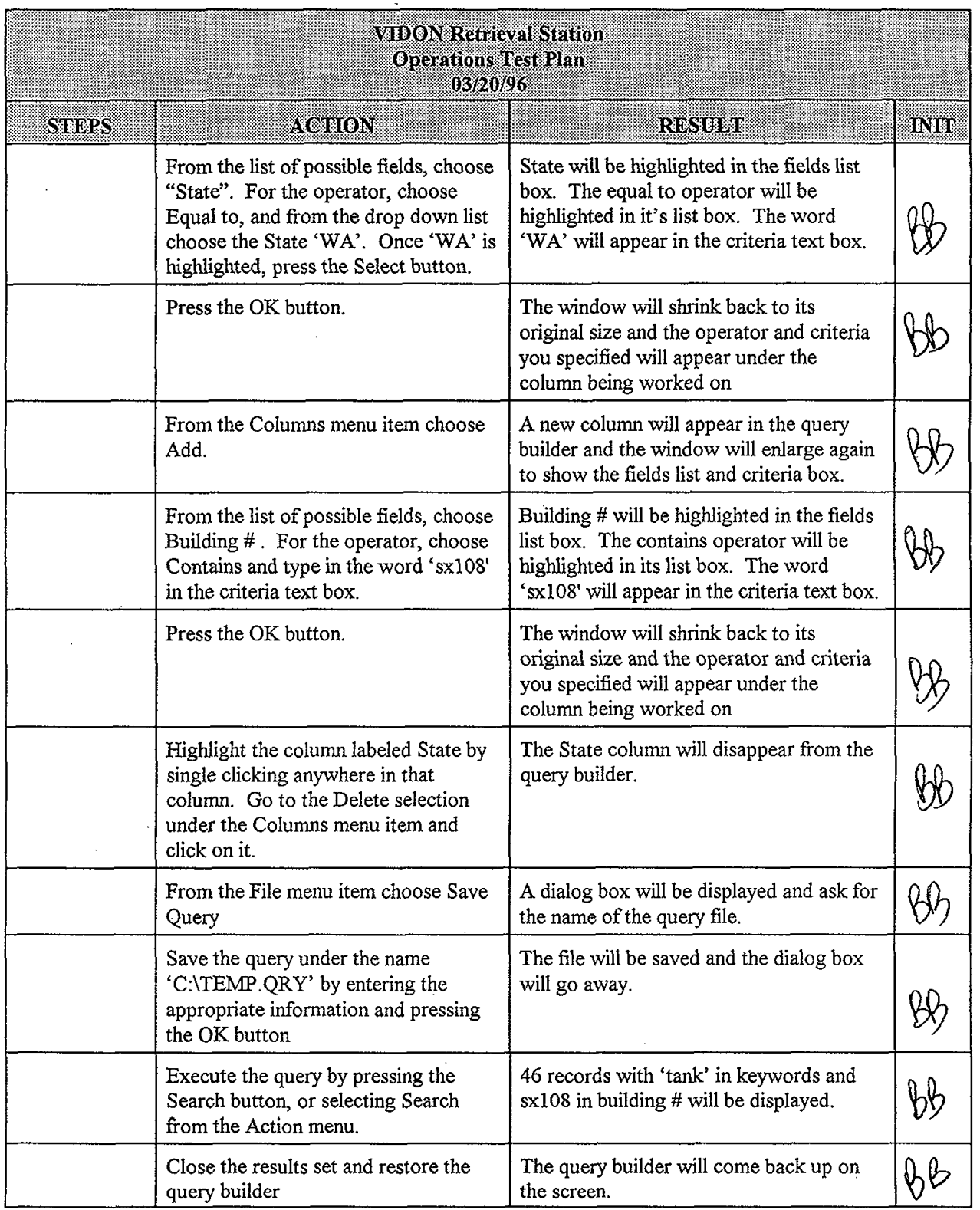




\begin{tabular}{|c|c|c|c|}
\hline STERS & 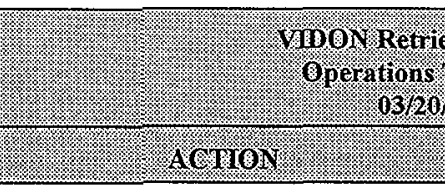 & $\begin{array}{l}\text { alstation } \\
\text { est rian : } \\
\text { 6. }\end{array}$ & 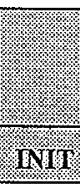 \\
\hline & $\begin{array}{l}\text { From the File menu option choose } \\
\text { Clear Query. }\end{array}$ & $\begin{array}{l}\text { All of the operators and criteria from the } \\
\text { query builder will be cleared. }\end{array}$ & $B$ \\
\hline & $\begin{array}{l}\text { From the File menu option choose } \\
\text { Open Query. }\end{array}$ & $\begin{array}{l}\text { You will be presented with a dialog box } \\
\text { asking for the name of a query to open. }\end{array}$ & 80 \\
\hline & $\begin{array}{l}\text { Open the query you saved in the } \\
\text { previous steps. }\end{array}$ & $\begin{array}{l}\text { The fields of the query builder will be } \\
\text { restored to what they looked like before } \\
\text { you did the Clear Query. }\end{array}$ & $B 8$ \\
\hline & $\begin{array}{l}\text { Execute the query again by pressing } \\
\text { the Search button. }\end{array}$ & $\begin{array}{l}\text { The same } 46 \text { records with 'tank' in } \\
\text { keywords and sx108 in building \# will be } \\
\text { displayed. }\end{array}$ & 88 \\
\hline $\begin{array}{l}\text { TD 01.03-02 } \\
\text { Predefined } \\
\text { tank query of } \\
\text { VIDON }\end{array}$ & $\begin{array}{l}\text { Bring up the Tank Query form by } \\
\text { either pressing the Tank Query button } \\
\text { or by clicking on the Tank Select } \\
\text { selection under the Query menu item. }\end{array}$ & The Tank Query form appears. & \\
\hline & $\begin{array}{l}\text { From the Tank name list box, choose } \\
\text { tank 241TX113. From the Photo Sets } \\
\text { list box, choose the date of } 9 / 19 / 95 \text {. }\end{array}$ & $\begin{array}{l}241 \mathrm{TX} 113 \text { will be selected in the tank } \\
\text { name list box and the date of } 9 / 19 / 1995 \\
\text { will appear in the Photo Sets list box. }\end{array}$ & $B 3$ \\
\hline & Press the OK button & $\begin{array}{l}\text { The query results form will be shown with } \\
\text { the results of your predefined query and } \\
\text { the make album message box is displayed. }\end{array}$ & bo \\
\hline & Choose Yes, to create the Album. & $\begin{array}{l}\text { Displayed will be the new album that was } \\
\text { created with all the images from the } \\
\text { results form. }\end{array}$ & Bh \\
\hline & Close the album without saving. & Previously displayed album is removed. & $B b$ \\
\hline $\begin{array}{l}\text { TD 01.03-03 } \\
\text { Tank Farms } \\
\text { group }\end{array}$ & $\begin{array}{l}\text { Start VDON software as a Tankfarms } \\
\text { User by double clicking on the } \\
\text { VIDON icon }\end{array}$ & Main VDDON retrieval screen will appear & $B$ \\
\hline & Select edit menu & $\begin{array}{l}\text { Confirm that Tank Comment option } \\
\text { appears }\end{array}$ & Bb \\
\hline
\end{tabular}




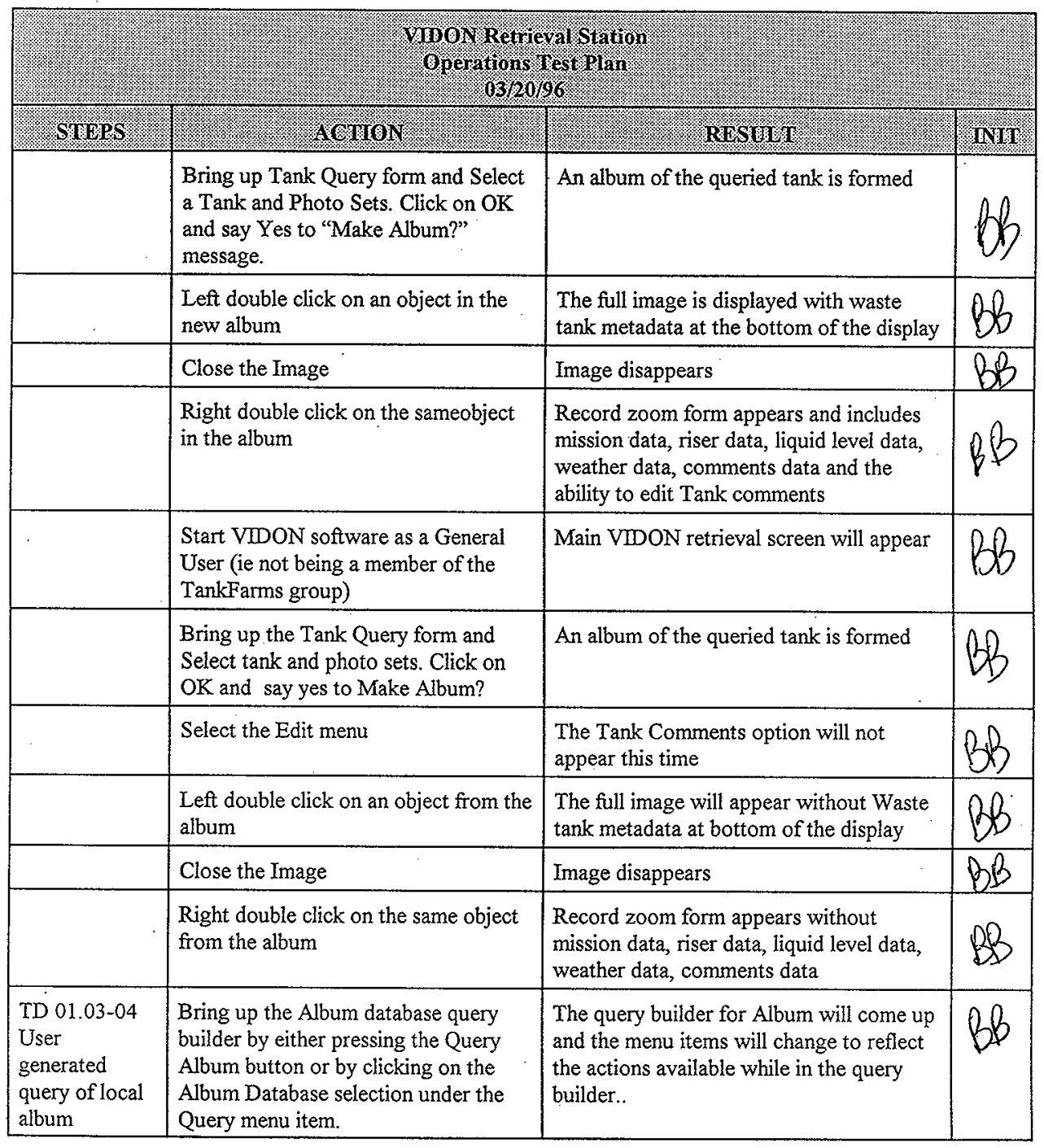




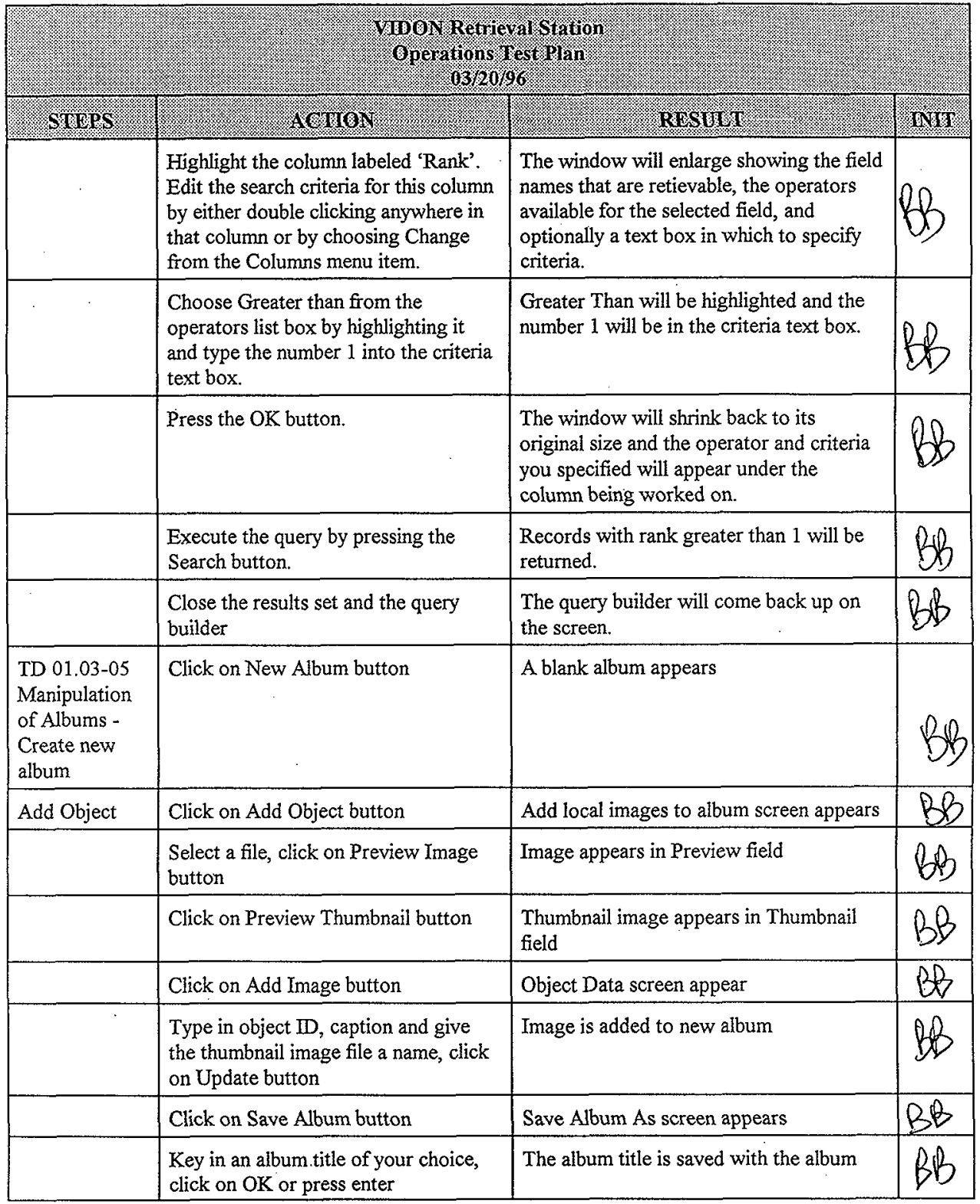




\begin{tabular}{|c|c|c|c|}
\hline . & 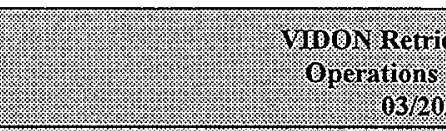 & $\begin{array}{l}\text { listation: } \\
\text { ertinan: } \\
6\end{array}$ & \\
\hline SHESPS & demron & RESSIET & INII \\
\hline Close aibum & Click on Close Album & Album is closed & 80 \\
\hline open existing & Click on Open Album & Open Album screen appears & \\
\hline & $\begin{array}{l}\text { Select the previously saved album title } \\
\text { and chose Open }\end{array}$ & $\begin{array}{l}\text { The saved album that you just requested } \\
\text { is opened }\end{array}$ & $b 3$ \\
\hline & $\begin{array}{l}\text { Click on the image from which } \\
\text { information is required }\end{array}$ & Image title is highlighted in red & \\
\hline . & Click on Object Information button & $\begin{array}{l}\text { Object Data screen appears containing } \\
\text { image information }\end{array}$ & Bh \\
\hline & Click on cancel button & Object Data screen closes & $B b$ \\
\hline & Click on Close Album button & Album closes & 88 \\
\hline $\begin{array}{l}\text { TD 01.03-06 } \\
\text { Metadata } \\
\text { viewing -local }\end{array}$ & $\begin{array}{l}\text { Confirm that the captions are being } \\
\text { displayed by going to the Options } \\
\text { menu and selecting Captions. }\end{array}$ & $\begin{array}{l}\text { A check mark will now apear next to } \\
\text { Captions on the Options menu }\end{array}$ & 88 \\
\hline & $\begin{array}{l}\text { Open an album containing local } \\
\text { images, click on an image, click on } \\
\text { Object Info button }\end{array}$ & Object Data form appears & A \\
\hline & $\begin{array}{l}\text { Click on Caption field, enter caption, } \\
\text { click on update button }\end{array}$ & $\begin{array}{l}\text { Object Data form closes, caption appears } \\
\text { on image in album }\end{array}$ & $B B$ \\
\hline VIDON image & $\begin{array}{l}\text { Open an album containing VIDON } \\
\text { images, double right click on an image }\end{array}$ & Record Zoom form appears & $B$ \\
\hline $\begin{array}{l}\text { TD 01.03-07 } \\
\text { Image }\end{array}$ & $\begin{array}{l}\text { Open an album, left double click on an } \\
\text { object in an album }\end{array}$ & Image is enlarged to medium resolution & DB \\
\hline & Click on copy button & Image Copy form appears & BA \\
\hline . & $\begin{array}{l}\text { Select format, select colors, check file } \\
\text { name and directory, click on Copy To } \\
\text { File button }\end{array}$ & Image is saved to the selected local file & Be \\
\hline & $\begin{array}{l}\text { Go to file manager, verify that file has } \\
\text { been saved to the specified location }\end{array}$ & & $B b$ \\
\hline
\end{tabular}




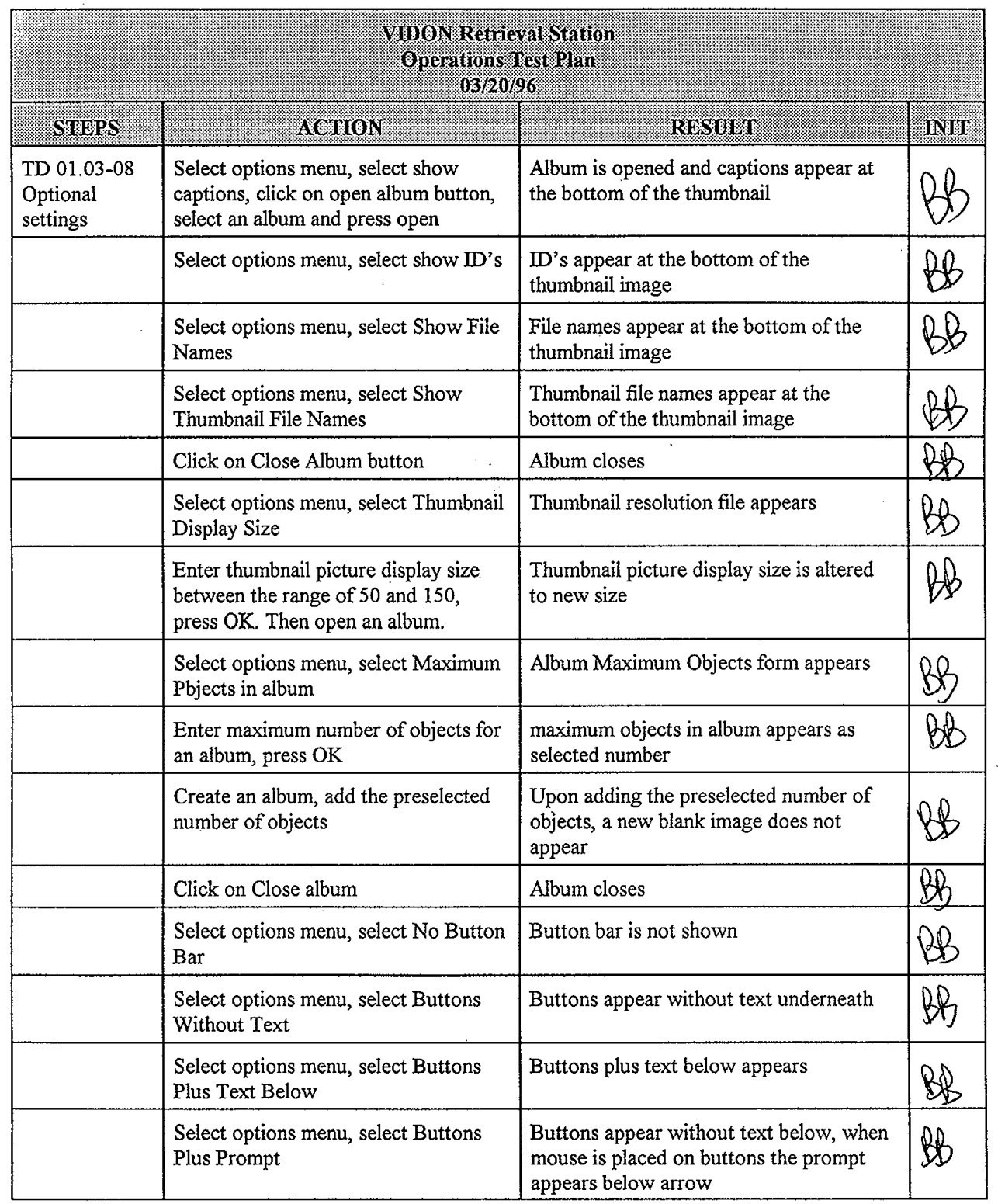




\begin{tabular}{|c|c|c|c|}
\hline 89 & & 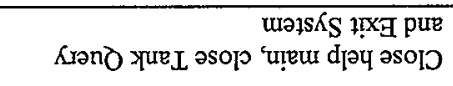 & \\
\hline 99 & 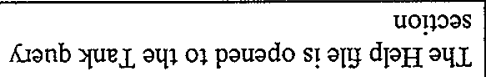 & 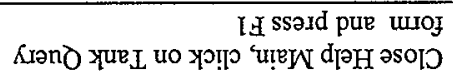 & \\
\hline 80 & 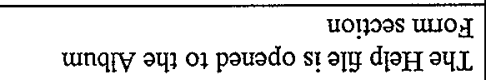 & 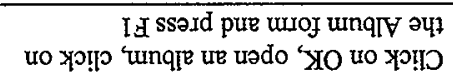 & \\
\hline 89 & sreadde wrof Hoddns jonpold 78 inoq & 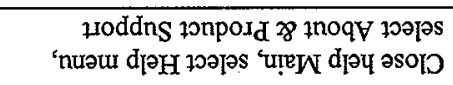 & \\
\hline ds & 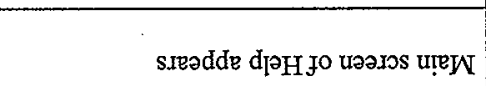 & 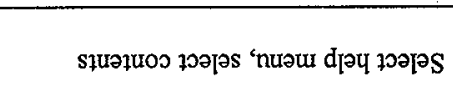 & 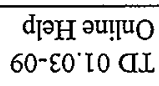 \\
\hline MIN & 4hosd & Nolderlor & Sagars \\
\hline & 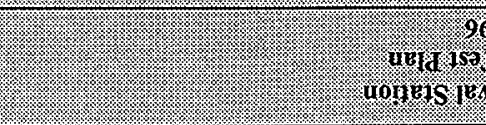 & 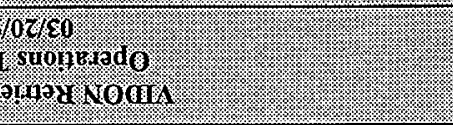 & \\
\hline
\end{tabular}

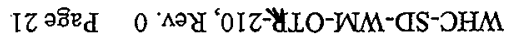


Rev. 0 WHC-SD-WM-OTR-210 Page 22

\begin{tabular}{|l|c|c|}
\hline Test Case \# & Exception & INT \\
\hline & NONe & BB \\
\hline & & \\
\hline & & \\
\hline & & \\
\hline & & \\
\hline Customer: \\
BB y nan \\
\hline Witness:
\end{tabular}

